\title{
Seasonal Changes Affect Root Prunasin Concentration in Prunus serotina and Override Species Interactions Between P. serotina and Quercus petraea
}

\author{
Piotr Robakowski $^{1}$ (D) Ernest Bielinis ${ }^{1} \cdot$ Jerzy Stachowiak $^{2}$ • \\ Iwona Mejza $^{3} \cdot$ Bartosz Bułaj $^{1}$
}

Received: 22 September 2015 / Revised: 18 February 2016 / Accepted: 29 February 2016 /Published online: 9 March 2016

(C) The Author(s) 2016. This article is published with open access at Springerlink.com

\begin{abstract}
The allocation of resources to chemical defense can decrease plant growth and photosynthesis. Prunasin is a cyanogenic glycoside known for its role in defense against herbivores and other plants. In the present study, fluctuations of prunasin concentrations in roots of Prunus serotina seedlings were hypothesized to be: (1) dependent on light, air temperature, and humidity; (2) affected by competition between Prunus serotina and Quercus petraea seedlings, with mulching with Prunus serotina leaves; (3) connected with optimal allocation of resources. For the first time, we determined prunasin concentration in roots on several occasions during the vegetative season. The results indicate that seasonal changes have more pronounced effects on prunasin concentration than light regime and interspecific competition. Prunus serotina invested more nitrogen in the synthesis of prunasin under highly restricted light conditions than in higher light environments. In full sun, prunasin in roots of Prunus serotina growing in a monoculture was correlated with growth and photosynthesis, whereas these relationships were not found
\end{abstract}

Electronic supplementary material The online version of this article (doi:10.1007/s10886-016-0678-y) contains supplementary material, which is available to authorized users.

Piotr Robakowski

pierrot@up.poznan.pl

1 Department of Forestry, Poznan University of Life Sciences, Wojska Polskiego 71E St., 60-625 Poznan, Poland

2 Department of Chemistry, Poznan University of Life Sciences, Wojska Polskiego 75 St., 60-625 Poznan, Poland

3 Department of Mathematical and Statistical Methods, Poznan University of Life Sciences, Wojska Polskiego 28 St., 60-637 Poznan, Poland when interspecific competition with mulching was a factor. The study demonstrates that prunasin concentration in Prunus serotina roots is the result of species-specific adaptation, light and temperature conditions, ontogenetic shift, and, to a lesser extent, interspecific plant-plant interactions.

Keywords Biomass allocation · Black cherry $\cdot$ Cyanogenic glycosides $\cdot$ Invasive species $\cdot$ Liquid chromatography $\cdot$ Oak · Photosynthesis · Prunasin · Prunus serotina

\section{Introduction}

Prunasin [(R)-mandelonitrile- 3 -D-glucopyranoside] is a cyanogenic glycoside, a class of specialized plant metabolites. It is present in more than 3000 plant species, including economically important species such as sorghum (Sorghum bicolor L. (Moench)) and cassava (Manihot esculenta Crantz.) (Swain and Poulton 1994a). Prunasin occurs in plant tissues of Rosaceae, Polypodiaceae, Myrtaceae, Saxifragaceae, Scrophulariaceae, and Myoporaceae, but is especially abundant in Rosaceae and Polypodiaceae, where it is found in all plant organs (Vetter 2000).

In the present study, prunasin was determined for the first time in roots of Prunus serotina seedlings under different light and temperature conditions on several occasions during the vegetative period. So far, only a few studies have considered prunasin concentration in roots, and one study found that bitter-kernelled genotypes had higher prunasin levels in their roots than non-bitter genotypes (Dicenta et al. 2002). The other cyanogenic glycosides, linamarin and lotaustralin, have been studied in cassava roots (Hernández et al. 1995; Okafor 2005). Linamarin levels in cassava roots depended on cultivar, and were around 20 times lower compared to linamarin levels in leaves (Okafor 2005). 
Several studies have shown significant differences in prunasin concentrations in leaves and twigs among species, varieties, cultivars, and individuals belonging to the same population (Burns et al. 2012; Goodger et al. 2004). For example, average prunasin concentrations in newly initiated leaves of Amelanchier alnifolia var. cusickii were three times greater than in A. alnifolia var. alnifolia (Brooke et al. 1984). Variations in the amount of cyanogenic glycosides can be attributed to differences in rates of their synthesis and to enzymatic degradation (Gleadow and Møller 2014; Vetter 2000).

In the case of tissue disruption, prunasin is degraded to hydrogen cyanide, glucose, and benzaldehyde by $\beta$ glucosidase prunasin hydrolase and mandelonitirile lyase (Sánchez-Pérez et al. 2012). After being hydrolyzed by endogenous enzymes, prunasin decomposes into hydrogen cyanide $(\mathrm{HCN})$, a respiratory poison that inhibits the activity of metalloenzymes, including cytochrome $c$ oxidase (Leavesley et al. 2008). Highly toxic for aerobic organisms, $\mathrm{HCN}$ inhibits respiratory function in cells, and thus impedes seed germination and plant growth rates (Gleadow and Møller 2014). HCN is produced when plant tissue has been damaged, which suggests that prunasin may defend cyanogenic plants against herbivores (Agrawal et al. 2012; Ballhorn et al. 2011a; Swain and Poulton 1994b). However, cyanogenic compounds do not increase resistance to pathogens (e.g., Lieberei 2006), but plants containing cyanide glycosides are less attractive to insects. For example, when feeding intensities of adult Japanese beetles [Popillia japonica (Newm.)] were compared among 27 taxa of Prunus (including Prunus serotina), feeding decreased exponentially as endogenous foliar cyanide production increased (Patton et al. 1997). The results of numerous other studies confirm that cyanogenic glycosides, including prunasin in roots (Dicenta et al. 2002; Mulas 1994), play a crucial role in plant defense against pests. Additionally, prunasin functions as a repellent and an $\mathrm{N}$-storage compound, similar to other cyanogenic glycosides such as linustatin (Selmar et al. 1988; Swain and Poulton 1994b). The potential pathways for prunasin metabolism as well as $\mathrm{HCN}$ reassimilation in P. serotina seedlings were proposed by Swain and Poulton (1994b).

Usually, developing leaves show high levels of $\mathrm{HCN}$, and HCN levels decrease with leaf age (Brooke et al. 1984; Majak et al. 1980). In Eucalyptus cladocalyx F. Muell., HCN production gradually decreased during the vegetative season, when photosynthetic capacity and growth rate are increased (Gleadow et al. 1998; Gleadow and Woodrow 2000). Cyanogenic capacity in leaves of Eucalypthus polyanthemos is influenced largely by genetic factors, while environmental aspects, such as soil nitrogen content, have a smaller influence (Ballhorn et al. 2011a; Goodger et al. 2004). However, much less is known about variations of prunasin concentrations in roots of cyanogenic woody plants and how these concentrations depend on ecological factors and ecophysiological regulatory mechanisms.
$\mathrm{Du}$ et al. (1995) showed that cynanogenic glycosides in cassava are not only translocated from leaves to roots, but also synthesized in roots. However, there is a lack of information about the possible light effect on regulation of the synthesis and translocation of the cyanogenic glycosides. Miller et al. (2004) showed that there were no differences in cyanogenic glycoside concentrations in foliage, stem, or roots of Prunus turneriana (F.M. Bailey), Kalkman under different light treatments. When the effect of light on cyanogenic glycoside content was studied, conflicting results were obtained (Gleadow and Møller 2014). In leaves of Eucalyptus cladocalyx F. Muell., cyanogenic glycosides were decreased by shading (Burns et al. 2002). In contrast, Pteridium aquilinum and Trifolium repens showed higher concentrations of cyanogenic compounds in shade compared with plants adapted to full light (Cooper-Driver et al. 1977; Vickery et al. 1987). Our study is the first to investigate the effect of light acclimation of $P$. serotina seedlings on prunasin concentrations in roots.

Plant species growing within a community interact both above- and belowground (McHugh and Gehring 2006). In the case of $P$. serotina, the belowground plant-plant interaction may be affected by cyanogenic exudates released from roots that affect roots of other plants (Badri and Vivanco 2009; Bais et al. 2004, 2006). Such allelopathic interactions between cyanogenic plant species and their competitors may contribute to the biodiversity of plant communities (Del-Val and Crawley 2005). However, transport of cyanide in soils is mostly influenced by volatilization and decomposition. Accordingly, the high volatility of cyanide and soil microbial activity ensure that high levels of cyanide do not persist or accumulate in soil under natural conditions (Ubalua 2010). On the other hand, cyanide derived from cyanogenic glycosides, including prunasin, may form stable complexes with metals $\left(\mathrm{Fe}^{2+}\right.$, $\mathrm{Mn}^{2+}$, and $\mathrm{Cu}^{2+}$ ), making essential metals unavailable for plants (Ubalua 2010).

Genetic, physiological, and environmental effects on cyanogenic glycoside variability are poorly understood, particularly in tree species (Goodger et al. 2004). Approaches to define the growth environment and interspecific interactions are necessary to gain a better understanding of the role of prunasin in roots. Correlations between growth, physiological traits, and prunasin concentration in P. serotina roots growing in competition with $Q$. petraea under different light regimes should add insight into the life strategy of an invasive, cyanogenic species. According to optimal resource allocation theory, it has been assumed that an increase in prunasin concentration in P. serotina roots would be at the costs of a decrease in photosynthesis and growth (McKey 1974; Miller et al. 2004). A trade-off can be established between resource allocation into defense and growth (Gleadow et al. 2014). To our knowledge, no other studies have examined prunasin concentration in P. serotina roots growing in competition with another tree species under different light regimes. 
The objective of this study was to investigate changes in prunasin concentration in P. serotina roots in response to climatic conditions and competition with $Q$. petraea seedlings. We posited that prunasin in P. serotina roots would fluctuate during the vegetative season, depending on sampling time and climatic parameters. In some cases, shade plants are more vulnerable to herbivory than sun plants (Karolewski et al. 2010), and thus, prunasin concentrations might be higher in seedlings acclimated to shade compared to those growing in full sun. Interspecific competition, along with mulching with $P$. serotina leaves, also could alter prunasin concentrations in $P$. serotina roots. We made an attempt to elucidate relationships between prunasin concentration and morphological and physiological traits of P. serotina seedlings within the hypothesis of optimal resource allocation.

\section{Methods and Materials}

Plants Prunus serotina (Ehrh.) Borkh. is a deciduous tree or a small understory shrub native to North America. It grows under a wide range of climatic conditions. In its natural range, average annual precipitation is 970 to $1120 \mathrm{~mm}$, and mean annual temperatures are below $24{ }^{\circ} \mathrm{C}$. In the center of the natural range, January temperatures reach a maximum of 1 to $6{ }^{\circ} \mathrm{C}$ and a minimum of -11 to $-6{ }^{\circ} \mathrm{C}$. July temperatures reach a maximum of 27 to $29{ }^{\circ} \mathrm{C}$ and a minimum of 11 to $16^{\circ} \mathrm{C}$. Prunus serotina grows on a variety of soils, but does not tolerate very wet or dry conditions (Marquis 1990). In Europe, this species has invaded many types of plant communities (Csiszár et al. 2013; Möllerová 2005). At a young age, it can be classified as moderately shade tolerant, showing the highest growth rate in $25 \%$ full sun, and a slightly lower rate in $100 \%$ (Robakowski, unpublished). In European countries, $P$. serotina is considered to be an aggressive colonizer, outcompeting native tree species (Halarewicz 2011).

Quercus petraea (Matt.) Liebl. is a deciduous broad-leaved tree. In its natural range, mean annual temperatures are between 5 and $15{ }^{\circ} \mathrm{C}$, mean annual rainfall is 400 to $2500 \mathrm{~mm}$, mean maximum temperature of the hottest month is 10 to $20{ }^{\circ} \mathrm{C}$, and mean minimum temperature of the coldest month is -15 to $-8{ }^{\circ} \mathrm{C}$ (Forestry Compendium 2005). Quercus petraea is classified as shade-tolerant as a juvenile, but its light requirements increase with age (Zarzycki et al. 2002). It tolerates a wide range of soil conditions, but it is best-suited to well-aerated, not too wet, deep, and fertile soils (Modrzyński et al. 2006). In Poland and Germany, Q. petraea finds favorable conditions for natural regeneration beneath the canopy of pine stands (Kenk 1993). Natural regeneration of $Q$. petraea occurs together with the more abundant natural regeneration of $P$. serotina under the canopy of Pinus sylvestris (L.) stands of different age (Robakowski, personal observation).
Cultivation of Seedlings In October 2011, acorns of Quercus petraea were collected in a selected seed stand located in the Jarocin Forest Division, Western Poland. In March 2012, before seeding, a small fragment was cut out at the cap side of the acorns to synchronize germination time (Giertych and Suszka 2011). Seeds were sown in containers for germination, and seedlings were grown in peat and perlite $(3: 1 ; v / v)$ substrate.

Since P. serotina is a highly invasive species and therefore not allowed to be cultivated in forest nurseries in Poland, seedlings used in our experiments originated from natural regeneration occurring in large numbers in the "Zielonka" Experimental Forest, $27 \mathrm{~km}$ from Poznan $\left(52^{\circ} 33^{\prime} 29^{\prime \prime} \mathrm{N}\right.$; $\left.17^{\circ} 06^{\prime} 18^{\prime \prime} \mathrm{E}\right)$. At the beginning of May, one-yr.-old seedlings were unearthed, put into plastic boxes, and their roots were covered with humid humus. Seedlings were transported to the Poznan University of Life Sciences Dendrological Garden.

To reduce ontogenetic effects, seedlings of a similar size were selected. Quercus and Prunus seedlings were potted using $2257-\mathrm{L}$ pots filled with a mixture of sand, peat, and humus $(1 / 1 / 1 ; v / v / v)$. The $\mathrm{pH}$ of the substrate was neutral. Before planting, $100 \mathrm{~g}$ of fresh P. serotina leaves, cut into small pieces $\left(\sim 0.25 \mathrm{~cm}^{2}\right)$, were added to each of 90 pots and mixed with the substrate to enhance the expected allelopathic reaction. Mulching was repeated once a month from May to September with $10 \mathrm{~g}$ of freshly cut P. serotina leaves. In leaves used for mulching, prunasin concentrations were $2.86 \pm 048$ and $15.9 \pm 4.89 \mathrm{mg} \mathrm{g}^{-1} \mathrm{FW}$ (mean $\pm \mathrm{SE}, \mathrm{FW}-$ fresh weight, $N=4$ ) in May and August, respectively. The lowest leaf prunasin concentration was 1.93, and the highest value was $29.93 \mathrm{mg} \mathrm{g}^{-1} \mathrm{FW}$. Prunasin was not found in the substrate, even after mulching with $P$. serotina leaves. The seedlings were planted using cardboard templates to keep a $5 \mathrm{~cm}$ distance between them. In the control group, three Quercus seedlings or three Prunus seedlings were planted along the central axis of a pot. When grown in interspecific competition, Quercus seedlings were planted along the diameter of a pot, and six Prunus seedlings were distributed by threes along both sides of the Quercus seedlings. Five combinations were obtained using different numbers of seedlings and different mulching scenarios:

1) Q - three seedlings of Quercus petraea; 2) P - three seedlings of $P$. serotina; 3$) \mathrm{Q}+\mathrm{L}$ - three seedlings of $Q$. petraea + mulching with $P$. serotina leaves; 4) $\mathrm{Q}+\mathrm{P}$ - three seedlings of $Q$. petraea + six seedlings of $P$. serotina; 5) $\mathrm{Q}+$ $\mathrm{P}+\mathrm{L}-$ three seedlings of $Q$. petraea + six seedlings of $P$. serotina + mulching. All combinations are schematically shown in Fig. S1 (Supplementary Material). We focused on two combinations to investigate prunasin concentration in $P$. serotina roots: $\mathrm{P}$ and $\mathrm{Q}+\mathrm{P}+\mathrm{L}$.

One week after planting, the seedlings were fertilized using $15 \mathrm{~g}$ of the slow-releasing fertilizer 'Osmocote Exact Standard' (N, P, K, Mg - 15:9:12:2 and microelements) per pot. Every $2 \mathrm{~d}$, seedlings were watered up to field capacity by 
using an automatic irrigation system. Watering was less intensive under the low light regime (10\% full light). Seedlings were grown under experimental conditions from mid-May to the end of November.

Experimental Design The 225 pots were distributed into three blocks ( 75 pots per block). Each block was divided into three light treatments: LL (10 \%), ML (25\%), and HL (100\% or full irradiance). There were 25 pots in each light treatment. Five combinations of seedlings with or without mulching were distributed in split-plots (five pots per block, light treatment and combination). Each combination was repeated five times in each plot, i.e., 225 experimental units ( 5 repetitions $\times 5$ combinations $\times 3$ light treatments $\times 3$ blocks $=225$ pots $)$. We used two combinations, $\mathrm{P}$ and $\mathrm{Q}+\mathrm{P}+\mathrm{L}$ (90 pots), to investigate prunasin in P. serotina roots.

Every month, from June to September, we randomly chose one pot per block, light treatment, and combination to measure structural, morphological, and physiological seedling parameters. The measurements were conducted on two (prunasin concentration in roots, structural parameters, and gas exchange) or three seedlings (biomass allocation and chlorophyll $a$ fluorescence) of each species per pot. Every 2 wk., the position of the pots was randomly changed within a block and light treatment to homogenize light conditions.

Light Treatments Three different light treatments were established using a shading net; the optical proprieties of the net are described in Wyka et al. (2007). Photosynthetic photon flux (PPF) was measured simultaneously in shading tents above each pot and in the open space by using two light sensors (Spectrum Technologies, Inc., USA). Measurements of PPF were repeated on three occasions on cloudy days in May, July, and September. The relative values of light level were calculated using the following formula: $\mathrm{rPPF}(\%)=(\mathrm{PPF}$ in shade/PPF in the open) $\times 100$.

Meteorological Conditions Air temperature and relative humidity $(R H)$ were monitored with HOBO Pro v2 (OnSet Computers, Pocasset, MA, USA) under the experimental light environments throughout the growing season. Six HOBOs (two per light treatment) were fixed $80 \mathrm{~cm}$ above the ground and registered data every twenty min. Monthly mean temperature $\left(T_{\text {mean }}\right)$, monthly maximum temperature $\left(T_{\max }\right)$, monthly minimum temperature $\left(T_{\min }\right)$, and monthly mean $R H$ were calculated (Table 1). Microclimatic differences were most noticeable between both shade treatments and HL. Shading decreased monthly mean temperatures and increased monthly amplitudes and $R H$ compared to HL (Table 1). The coldest months were May and September, the hottest month was August. The differences between HL and ML in $T_{\text {mean }}$ were 1.62 in June, 1.71 in August, and $0.97{ }^{\circ} \mathrm{C}$ in September. The lowest $T_{\min }$ and the highest $T_{\max }$ values were observed in HL.
Morphological Traits In May, before the beginning of the experiment, the shoot length, $(S)$, root length $(R)$, the diameter at root collar $(D)$, and biomass allocation in ten seedlings of $Q$. petraea and ten seedlings of $P$. serotina were measured. The results were regarded as an absolute control. Shoot length, root length, and biomass allocation then were measured on five occasions once a month from June to November. The seedlings of the study species were divided into roots, shoots, and leaves, and were weighed. The leaves were scanned with a resolution of $300 \mathrm{dpi}$, and the leaf projected area was determined using the program "DigiShape" (Cortex Nova, Poland). Plant organs were dried at $65^{\circ} \mathrm{C}$ for $48 \mathrm{~h}$ (Pol-Eko, Poland), and dry mass (DM) was weighed (Sartorius, Germany).

The parameters describing biomass allocation in a seedling have been defined in Hunt et al. (2002); Portsmuth and Niinemets (2007); Poorter et al. (2012); Reich et al. (1998). Equations for calculating the parameters of biomass allocation are given in Supplementary Material.

Chlorophyll $\boldsymbol{a}$ Fluorescence Pots with seedlings (one pot per block, light treatment, and combination) were transported to the laboratory and kept in a dark room for $12 \mathrm{~h}$. A fully expanded leaf was selected from the top part and the same exposure of a crown. A leaf-clip was attached to the leaf, and the leaf chamber of the plant efficiency analyzer (PEA, Hansatech, Norfolk, UK) was mounted. The continuous red light of $1 \mathrm{~s}$ induced chlorophyll $a$ fluorescence. The induction light was $3200 \mu \mathrm{mol} \mathrm{m} \mathrm{m}^{-2} \mathrm{~s}^{-1}$. Basic fluorescence yield $\left(F_{0}\right)$ and maximal fluorescence yield $\left(F_{m}\right)$ were calculated by the algorithm from fluorescence induction curves, and maximum quantum yield of PSII photochemistry $\left(F_{v} / F_{m}=F_{m}-F_{0} / F_{m}\right)$ ( $F_{v}$ - variable fluorescence) was calculated using the built-in software of the PEA (Operating Instructions for PEA 1999).

Gas Exchange Net assimilation of $\mathrm{CO}_{2}(A)$, leaf transpiration $(E)$, and stomatal conductance $\left(g_{\mathrm{s}}\right)$ was measured immediately after chlorophyll $a$ fluorescence on the same leaf by using the gas exchange analyzer LCA-4 (ADC, Ltd., Hoddesdon, UK) equipped with the broadleaf chamber (PLC4B). Air flow was $138 \mu \mathrm{mol} \mathrm{s}{ }^{-1}$, and $\mathrm{CO}_{2}$ concentration in inlet air was $380 \mu \mathrm{mol} \mathrm{mol}^{-1}$. Leaf temperature was controlled by thermocouple and ranged from 26 to $27^{\circ} \mathrm{C}$. Relative air humidity in a leaf chamber was approximately $55 \%$. To stabilize air humidity in the leaf chamber, inlet air was enriched with water vapor by using an air humidifier (CF-2658, Comefresh Electronic Industry, Co. Ltd., China). Light was provided by a diode lamp (Parathom, PAR, day light, 4.5 W, Osram). Gas exchange was measured at the saturation light level of $1200 \mu \mathrm{mol} \mathrm{m} \mathrm{m}^{-2} \mathrm{~s}^{-1}$. The leaf was placed in the leaf chamber and was given 20 to $30 \mathrm{~min}$ to acclimate to the leaf chamber conditions. The window of the leaf chamber was darkened, and dark respiration $\left(R_{\mathrm{d}}\right)$ was measured for $15 \mathrm{~min}$. The lamp then was switched on, and gas exchange was measured for 
Table 1 Meteorological conditions during the experiment. Mean $( \pm \mathrm{SE})$ monthly, minimum, maximum monthly temperatures, and mean monthly relative humidity $(\mathrm{RH})$ in three light treatments: $10 \%$ low light (LL), $25 \%$ medium light (ML) or $100 \%$ high light (HL) of full natural sun light

\begin{tabular}{llllll}
\hline Month & $\begin{array}{l}\text { Light treatment } \\
(\% \text { of full PAR })\end{array}$ & $\begin{array}{l}\text { Mean monthly } \\
\text { temp. }\left({ }^{\circ} \mathrm{C}\right)\end{array}$ & $\begin{array}{l}\text { Minimum monthly } \\
\text { temp. }\left({ }^{\circ} \mathrm{C}\right)\end{array}$ & $\begin{array}{l}\text { Maximum monthly } \\
\text { temp. }\left({ }^{\circ} \mathrm{C}\right)\end{array}$ & $\begin{array}{l}\text { Mean monthly } \\
\text { RH }(\%)\end{array}$ \\
\hline May & - & $15.87 \pm 0.15$ & -0.23 & 35.08 & $68.65 \pm 0.44$ \\
June & 10 & $16.24 \pm 0.11$ & 4.06 & 30.82 & $80.83 \pm 0.39$ \\
& 25 & $15.02 \pm 0.14$ & 4.04 & 31.03 & $82.40 \pm 0.39$ \\
& 100 & $16.64 \pm 0.12$ & 3.49 & 33.21 & $80.50 \pm 0.39$ \\
August & 10 & $17.99 \pm 0.11$ & 6.08 & 35.29 & $83.80 \pm 0.39$ \\
& 25 & $17.10 \pm 0.11$ & 6.15 & 35.80 & $85.64 \pm 0.39$ \\
& 100 & $18.81 \pm 0.13$ & 4.19 & 35.90 & $81.66 \pm 0.43$ \\
September & 10 & $13.63 \pm 0.10$ & 2.69 & 31.56 & $86.70 \pm 0.34$ \\
& 25 & $13.35 \pm 0.10$ & 2.90 & 31.38 & $88.62 \pm 0.33$ \\
& 100 & $14.32 \pm 0.13$ & 1.34 & 34.81 & $82.65 \pm 0.43$ \\
\hline
\end{tabular}

$30 \mathrm{~min}$. Data were registered every min to generate a curve of photosynthesis from the induction to a stable saturation level. Five values from the stable phase of a curve were used to calculate maximum net assimilation rate $\left(A_{\max }\right)$. Water use efficiency was calculated as a ratio of $A_{\max }$ to $E$. $A_{\max }$ was expressed in $\mu \mathrm{mol} \mathrm{m} \mathrm{m}^{-2} \mathrm{~s}^{-1}$ and $\mathrm{nmol} \mathrm{g}^{-1} \mathrm{DM} \mathrm{s}^{-1}$. Nitrogen concentration was determined in the same leaves as net $\mathrm{CO}_{2}$ assimilation rate to calculate photosynthetic nitrogen use efficiency (PNUE, $\mu \mathrm{mol} \mathrm{CO} \mathrm{CO}_{2} N^{-1} \mathrm{~s}^{-1}$ ).

\section{Prunasin Concentration in Roots of Prunus serotina} Prunasin concentration in roots of the $P$. serotina seedlings was determined using high performance liquid chromatography (HPLC) (De Nicola et al. 2011; Vetter 2000). To avoid possible interference of the results caused by tannins and plant pigments in the matrix, active carbon was added into the extract as scavenger (Berenguer-Navarro et al. 2002).

Sampling of Plant Material Seedlings were removed from pots and their roots were thoroughly washed with tap water. In the laboratory, the main root was measured and at the midway point, a fragment of the root was cut and weighed. Fresh mass of root samples was $200 \mathrm{mg}$. Samples were put into precooled Eppendorf tubes and stored at $-25{ }^{\circ} \mathrm{C}$. Root samples for prunasin concentration analyses were collected on four occasions: in May before planting and during the experiment at the end of June, July, and September. The total number of samples was ten absolute control + three repetitions in time $\mathrm{x}$ three blocks $\mathrm{x}$ three light treatments $\mathrm{x}$ two combinations of competition $\mathrm{x}$ two seedlings per pot $=118$.

Prunasin Extraction Root samples of $200 \mathrm{mg}$ were shaken with $10 \mathrm{ml}$ methanol for approximately $10 \mathrm{~h}$ at room temperature. Carbon was activated at $200{ }^{\circ} \mathrm{C}$ and kept in a desiccator. Then, $0.5 \mathrm{~g}$ of activated carbon were added to leaf extracts, and mixtures were centrifuged at $3000 \mathrm{rpm}$ for $10 \mathrm{~min}$. The supernatant was filtered through a $0.45 \mu \mathrm{m}$ nylon filter. Aliquots were injected directly into the column.
HPLC Analyses were conducted with Separations Module 2695 (Waters, USA), using the UV/Visible 2489 detector (Waters). Determination of prunasin was performed isocratically using the SunFireTM C18 column $(4.6 \times 250 \mathrm{~mm}, 5 \mu \mathrm{m})$ together with the precolumn Waters $(4.6 \times 20 \mathrm{~mm})$. The temperature of the column was stabilized at $40{ }^{\circ} \mathrm{C}$. The methanol: water $(15: 85 \mathrm{v} / \mathrm{v})$ solution was used as eluent at $1.5 \mathrm{ml} / \mathrm{min}$ flow rate, and UV detection was set at $218 \mathrm{~nm}$.

The concentration of prunasin in extracts was calculated from the calibration curve obtained using commercially available chromatographically purified prunasin (ABCR GmbH \& Co. KG, Karlsruhe, Germany) as a standard. Prunasin concentration was first expressed as $\mathrm{mg}^{-1}$ root fresh mass, and it was recalculated using fresh weight to dry weight root ratio and expressed as $\mathrm{mg} \mathrm{g}^{-1} \mathrm{DM}$.

Nutrient Concentration Nitrogen, phosphorous, potassium, calcium, and magnesium concentrations were determined using the same leaves on which chlorophyll $a$ fluorescence and gas exchange had been measured. Leaves were sampled on four occasions: in May (absolute control at the start of the experiment), June, August, and September. Total nitrogen content was determined using the Kjeldahl method. The digestion of leaf samples was conducted with a digestion system with sulfuric acid at $420{ }^{\circ} \mathrm{C}$ (Foss Tecator). Nitrogen was determined by distillation with water vapor in a ParnasWagner apparatus. For determination of $\mathrm{P}, \mathrm{K}, \mathrm{Mg}$, and $\mathrm{Ca}$, leaf samples were combusted at $500{ }^{\circ} \mathrm{C}$ for $8 \mathrm{~h}$. The ash was dissolved in $\mathrm{HCl}$, and the solution was used for further analyses. Phosphorous concentration in leaves was determined using the spectrophotometric molybdovanadate method. Absorbance was measured using a Specol 21 spectrophotometer (Carl Zeiss Jena, Germany) and compared with the calibration curve obtained from the standards. Magnesium was determined with Atomic Absorption Spectrometry using AAS 1 N (Carl Zeiss Jena, Germany). Photoelectric flame 
photometry (FlaPho 40, Carl Zeiss Jena, Germany) was applied to determine potassium and calcium concentrations. All nutrient analyses in leaves were conducted at the Department of Chemistry, Poznan University of Life Sciences, Poland.

Statistical Analyses Before analysis, the data were tested for normality and homogeneity of variance. When necessary, data were logarithmically transformed $\left[\left(z=\log _{10}(y+1)\right]\right.$ or the function $z=\arcsin \sqrt{p}$ was applied to obtain normal distribution. The effects of sampling time, light, and combination on prunasin in P. serotina roots was tested using analysis of variance in split-split plot design. This experimental design is also called "split-split plot in time" (Qiunn and Keough 2002). The linear model of ANOVA in split-split plot design is described in Supplementary Material.

To determine the relationship between morphological, architectural, structural, and physiological parameters and prunasin concentration in roots of $P$. serotina, we used analysis of correlation. Pearson's coefficients of correlation $(r)$ with probabilities were calculated. Additionally, linear regression between the measured traits and prunasin concentration was analyzed in P. serotina seedlings growing in one of two combinations: $\mathrm{P}$ or $\mathrm{Q}+\mathrm{P}+\mathrm{L}$ under high light. All statistical analyses were conducted using Statistica 10.0 (StatSoft, Inc., Tulsa, USA) and Sigmaplot 13.0.

\section{Results}

Effects of Microclimatic Conditions and Competition on Prunasin Concentration Prunasin concentration in

Table 2 Analysis of variance for prunasin concentration in roots of Prunus serotina seedlings acclimated to one of three light regimes: $10 \%$ low light (LL), $25 \%$ medium light (ML), or $100 \%$ high light (HL) of full natural sun light. Samples were taken on three occasions: in June (DOY 176, DOY - day of year), in August (DOY 238), and in September (DOY 273). The split-split plot model of ANOVA was applied

\begin{tabular}{|c|c|c|c|c|c|}
\hline Source of variance & Effect & Degrees of freedom & MS & $F$ & $P$ \\
\hline Block & Random & 2 & 0.22 & 0.21 & 0.065 \\
\hline Time of sampling & Fixed & 2 & 28.70 & 26.95 & 0.005 \\
\hline Error I (Block $\times$ Time of sampling) & Random & 4 & 1.07 & 0.67 & 0.626 \\
\hline Light & Fixed & 2 & 6.42 & 4.03 & 0.045 \\
\hline Time of sampling $\times$ Light & Fixed & 4 & 13.58 & 8.53 & 0.002 \\
\hline Error II $($ Block $\times$ Light + Block $\times$ Time $\times$ Light $)$ & Random & 12 & 1.59 & 1.13 & 0.401 \\
\hline Competition with mulching & Fixed & 1 & 0.27 & 0.19 & 0.666 \\
\hline Time of sampling $\times$ Competition with mulching & Fixed & 2 & 0.58 & 0.411 & 0.669 \\
\hline Light $\times$ Competition with mulching & Fixed & 2 & 2.01 & 1.42 & 0.269 \\
\hline Time of sampling $\times$ Light $\times$ Competition with mul. & Fixed & 4 & 3.55 & 2.51 & 0.081 \\
\hline Error III & Random & 17 & 1.41 & & \\
\hline Total & & 52 & & & \\
\hline
\end{tabular}

$P$. serotina roots was determined on four occasions under different conditions of air temperature and humidity (Table 1). The lowest mean prunasin concentration was in May. Prunasin in June was lower than in August, but did not differ significantly from September in split-split plot ANOVA and Tukey's test (Tables 2 and 3). When compared with May, prunasin increased eleven fold in August and approximately six fold in June and September (Table 3). Concentration was positively correlated with $T_{\min }$, with $T_{\min }$, explaining $54 \%$ of the variation (Fig. 1).

Prunasin concentration differed among the seedlings acclimated to different light environments. The highest concentration was found in plants grown in LL, which differed from those in HL, but not in ML (Tables 2 and 3). The significant interaction between sampling time and light indicates that the effect of sampling time was modified by the light conditions. Prunasin was highest in LL compared with ML and HL in September (Table 3). When the data from all light treatments were pooled, there were no differences in prunasin concentration between $P$. serotina seedlings growing in a monoculture and $\mathrm{Q}+\mathrm{P}+\mathrm{L}$. The interactions between the sampling time or light and combination were not significant (Table 2). Mean root DM in HL was approximately nine times higher than in LL and 2.7 times higher in ML. Thus, when prunasin concentrations expressed per mean root DM were compared among light treatments, the highest amount of was produced in HL $\left(31.3 \pm 18.7,15.4 \pm 10.8\right.$, and $7.8 \pm 3.9 \mathrm{mg} \mathrm{g}^{-1}$ root DM in HL, ML, and LL, respectively), suggesting that the differences among the light treatments are due, at least partially, to a shift in ontogenetic development.

with block, time of sampling, light treatment, combination, and interactions as the sources of variance. The differences were significant at $P \leq 0.05$. MS - mean sum of squares, $F$ - value of Snedecor's function, in bold - statistically significant at $P<0.05(N=106, N-$ number of seedlings) 
Table 3 Mean $( \pm$ SE)

concentration of prunasin in roots expressed per root dry mass of Prunus serotina seedlings in function of time, light treatments, combinations of seedlings, and mulching, and interactions. The different letters indicate that the mean values are significantly different in Tukey's a posteriori test at $\alpha=0.05(\alpha-$ level of significance). DOY - day of year, LL - low light (10\%), ML medium light (25\%), HL - high light $(100 \%), \mathrm{P}$ - three $P$. serotina seedlings (monoculture), $\mathrm{Q}+\mathrm{P}+$ $\mathrm{L}$ - three Quercus petraea + six $P$. serotina + mulching with $P$. serotina leaves

\begin{tabular}{|c|c|c|c|c|}
\hline \multicolumn{2}{|l|}{ Effects } & \multirow{2}{*}{$\frac{N}{9}$} & \multicolumn{2}{|c|}{ Mean $\pm \mathrm{SE}\left(\mathrm{mg} \mathrm{g}^{-1} \mathrm{DM}\right)$} \\
\hline Control & May & & $3.45 \pm 0.52$ & \\
\hline \multirow[t]{3}{*}{ Time of sampling } & June (DOY 176) & 34 & $19.95 \pm 2.12$ & $\mathrm{a}$ \\
\hline & August (DOY 238) & 36 & $39.50 \pm 3.85$ & $\mathrm{~b}$ \\
\hline & September (DOY 269) & 36 & $18.51 \pm 4.90$ & $\mathrm{a}$ \\
\hline \multirow[t]{3}{*}{ Light } & LL & 36 & $30.33 \pm 4.37$ & $\mathrm{a}$ \\
\hline & ML & 34 & $27.52 \pm 4.41$ & $\mathrm{ab}$ \\
\hline & HL & 36 & $20.50 \pm 4.41$ & $\mathrm{~b}$ \\
\hline \multirow[t]{2}{*}{ Competition } & $\mathrm{P}$ & 52 & $26.02 \pm 3.88$ & \\
\hline & $\mathrm{Q}+\mathrm{P}+\mathrm{L}$ & 54 & $26.18 \pm 3.42$ & \\
\hline \multirow[t]{9}{*}{ Time of sampling $\times$ light } & $176 \times \mathrm{LL}$ & 12 & $16.68 \pm 4.24$ & $\mathrm{a}$ \\
\hline & $176 \times \mathrm{ML}$ & 10 & $26.51 \pm 3.10$ & $\mathrm{a}$ \\
\hline & $176 \times \mathrm{HL}$ & 12 & $17.74 \pm 2.42$ & $\mathrm{a}$ \\
\hline & $238 \times \mathrm{LL}$ & 12 & $32.79 \pm 6.60$ & $\mathrm{a}$ \\
\hline & $238 \times \mathrm{ML}$ & 12 & $45.45 \pm 5.98$ & $\mathrm{a}$ \\
\hline & $238 \times \mathrm{HL}$ & 12 & $40.25 \pm 7.43$ & $\mathrm{a}$ \\
\hline & $269 \times \mathrm{LL}$ & 12 & $41.53 \pm 8.36$ & $\mathrm{a}$ \\
\hline & $269 \times \mathrm{ML}$ & 12 & $10.42 \pm 3.28$ & $\mathrm{~b}$ \\
\hline & $269 \times \mathrm{HL}$ & 12 & $3.57 \pm 0.73$ & $\mathrm{~b}$ \\
\hline \multirow[t]{6}{*}{ Time of sampling $\times$ competition } & $177 \times \mathrm{P}$ & 16 & $21.28 \pm 3.38$ & \\
\hline & $177 \times \mathrm{Q}+\mathrm{P}+\mathrm{L}$ & 18 & $18.77 \pm 2.77$ & \\
\hline & $238 \times \mathrm{P}$ & 18 & $36.60 \pm 6.32$ & \\
\hline & $238 \times \mathrm{Q}+\mathrm{P}+\mathrm{L}$ & 18 & $42.40 \pm 4.57$ & \\
\hline & $269 \times \mathrm{P}$ & 18 & $19.65 \pm 8.10$ & \\
\hline & $269 \times \mathrm{Q}+\mathrm{P}+\mathrm{L}$ & 18 & $17.37 \pm 6.01$ & \\
\hline \multirow[t]{6}{*}{ Light $\times$ competition } & $\mathrm{LL} \times \mathrm{P}$ & 18 & $30.02 \pm 6.57$ & \\
\hline & $\mathrm{LL} \times \mathrm{Q}+\mathrm{P}+\mathrm{L}$ & 18 & $30.65 \pm 6.17$ & \\
\hline & $\mathrm{ML} \times \mathrm{P}$ & 16 & $24.66 \pm 7.64$ & \\
\hline & $\mathrm{ML} \times \mathrm{Q}+\mathrm{P}+\mathrm{L}$ & 18 & $30.06 \pm 5.12$ & \\
\hline & $\mathrm{HL} \times \mathrm{P}$ & 18 & $23.23 \pm 6.65$ & \\
\hline & $\mathrm{HL} \times \mathrm{Q}+\mathrm{P}+\mathrm{L}$ & 18 & $17.82 \pm 6.06$ & \\
\hline
\end{tabular}

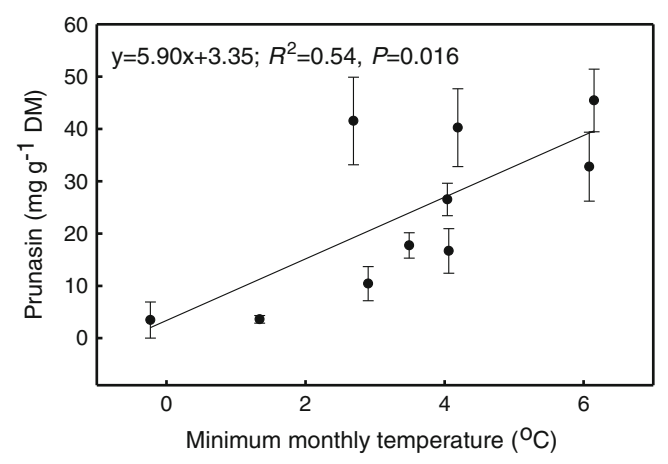

Fig. 1 The relationship between the minimum monthly temperature and mean prunasin concentrations (means $\pm \mathrm{SE}$ ) in roots of Prunus serotina. Prunasin concentration was determined in May, June, August, and September. The equation of linear regression, coefficient of determination $\left(R^{2}\right)$ with probability $(P)$ obtained from the analysis of variance in regression are given $(N=10, N$ - pairs of the values of minimum monthly temperature and mean prunasin concentration per light treatment)
Correlation between Biometrical Parameters and Prunasin Pooling of all data led to an increase of prunasin with declining root weight ratio $(R W R)\left(R^{2}=0.32, P<0.001\right)$. In $\mathrm{LL}$, the monoculture, and $\mathrm{Q}+\mathrm{P}+\mathrm{L}$, there were no correlations between morphological or architectural parameters of $P$. serotina seedlings and prunasin concentration (Table 4). A decrease in prunasin was correlated with increasing $R W R$ in both ML and HL, and with leaf mass to area ratio (LMA) in HL. In contrast, prunasin decreased with shoot length to shoot diameter at root collar ratio $(S L / S D)$ in ML and root dry weight $\left(W_{R}\right)$ in HL. Prunasin concentration was positively related to root to shoot ratio $(R / S)$, leaf weight ratio $(L W R)$, and leaf area ratio $(L A R)$ in both shade treatments, and to $L M A$ in ML (Table 4).

Relationships between Physiological Characteristics and Prunasin Significant correlations between physiological parameters and prunasin concentration were found mainly in the 
Table 4 Correlation between prunasin concentration in roots and morphological and architectural parameters of Prunus serotina seedlings growing in $10 \%$ low light (LL), $25 \%$ medium light (ML), or $100 \%$ high light (HL) of full natural sun light and in one of two combinations of seedlings: P (three $P$. serotina seedlings) or $\mathrm{Q}+\mathrm{P}+\mathrm{L}$ (three Quercus petraea $+\operatorname{six}$ P. serotina + mulching with P. serotina leaves). All data from three sampling dates (June, August, and September) were analyzed. $R L$ - root length, $S L$ - shoot length, $S D$ - shoot diameter at root collar, $R L R$ - root length ratio, $W_{R}$ - root dry weight, $W_{S}$ - shoot dry weight, $W_{L}$ - leaves dry weight, $W$-total seedling dry weight, $A_{L}$ - leaf area, $R / S$-root: shoot ratio, $R W R$ - root weight ratio, $S W R$ - shoot weight ratio, $L W R$ - leaf weight ratio, $L A R$ - leaf area ratio, $L M A$ - leaf mass to area ratio. The definitions of the calculated parameters are given in Supplementary Material. $r$ - Pearson's coefficient of correlation, ${ }^{*} 0.01 \leq P<0.05,{ }^{* *} 0.001 \leq P<0.01,{ }^{* * *} P<0.001$, in bold $-r$ statistically significant $(N=17)$

\begin{tabular}{|c|c|c|c|}
\hline \multirow[t]{2}{*}{$\begin{array}{l}\text { Morphological and } \\
\text { architectural parameters }\end{array}$} & \multicolumn{3}{|c|}{$\begin{array}{l}\text { Pearson's coefficient of correlation } \\
\text { prunasin vs. parameter }\end{array}$} \\
\hline & LL & ML & $\mathrm{HL}$ \\
\hline $\mathrm{RL}(\mathrm{mm})$ & 0.373 & -0.245 & -0.227 \\
\hline SL (mm) & 0.080 & 0.217 & -0.104 \\
\hline $\mathrm{SD}(\mathrm{mm})$ & -0.158 & -0.134 & -0.316 \\
\hline $\mathrm{SL} / \mathrm{SD}$ & -0.119 & $-0.700^{* *}$ & -0.378 \\
\hline $\operatorname{RLR}\left(\mathrm{m} \mathrm{g}^{-1}\right)$ & -0.132 & 0.142 & 0.245 \\
\hline $\mathrm{W}_{\mathrm{R}}(\mathrm{g})$ & 0.154 & -0.460 & $-0.615^{* *}$ \\
\hline $\mathrm{W}_{\mathrm{S}}(\mathrm{g})$ & 0.275 & -0.131 & -0.431 \\
\hline $\mathrm{W}_{\mathrm{L}}(\mathrm{g})$ & 0.187 & -0.166 & -0.370 \\
\hline W (g) & 0.208 & -0.258 & -0.445 \\
\hline $\mathrm{A}_{\mathrm{L}}\left(\mathrm{m}^{2}\right)$ & 0.221 & -0.055 & -0.199 \\
\hline $\mathrm{R} / \mathrm{S}$ & 0.096 & $0.657^{* *}$ & $0.804^{* * * *}$ \\
\hline RWR & -0.173 & $-0.735^{* *}$ & $-0.827^{* * *}$ \\
\hline SWR & -0.139 & 0.304 & 0.324 \\
\hline LWR & 0.261 & $0.533^{*}$ & $0.723^{* *}$ \\
\hline LAR $\left(\mathrm{m}^{2} \mathrm{~g}\right)$ & 0.055 & $0.690^{* * *}$ & $0.777^{* * * *}$ \\
\hline LMA $\left(\mathrm{g} \mathrm{m}^{-2}\right)$ & 0.467 & $0.538^{*}$ & $-0.564^{*}$ \\
\hline
\end{tabular}

shade treatments. In HL, only a decrease in prunasin with greater WUE (water use efficiency) was significant (Table 5). In LL, prunasin concentration was positively correlated with nitrogen content per unit leaf area, but not when $\mathrm{N}$ was expressed per unit leaf dry mass. Prunasin was negatively correlated with $F_{v} / F_{m}$ and $E$. In $\mathrm{ML}$, the important photosynthetic parameters $\left(A_{\max }\right.$ and $P N U E$ ) increased with higher prunasin concentrations (Table 5).

\section{Effects of Competition with Mulching on Prunasin} Concentration In HL, the relationships between $L A R, L W R$, and root prunasin were significant for $P$. serotina seedlings growing in monoculture, but this was not the case in $\mathrm{Q}+$ $\mathrm{P}+\mathrm{L}$ (competition with mulching) (Fig. 2a, b). Only with $R W R$, a decrease in prunasin concentration was significant in both treatments (Fig. 2c).
Table 5 Correlation between prunasin concentration in roots and structural, and physiological parameters of Prunus serotina seedlings growing in $10 \%$ low light (LL), $25 \%$ medium light (ML), or $100 \%$ high light (HL) of full natural sun light and in one of two competition treatment: $P$ (three $P$. serotina seedlings) or $\mathrm{Q}+\mathrm{P}+\mathrm{L}$ (three Quercus petraea $+\operatorname{six} P$. serotina + mulching with $P$. leaves). All data from three sampling dates (June, August, and September) were pooled. Chl tot - total chlorophyll content in leaf, $N$ - nitrogen content in leaf, $F_{v} / F_{m}-$ maximum quantum yield of PSII photochemistry, $R_{d}$ dark respiration, $A_{\max }-$ maximum net $\mathrm{CO}_{2}$ assimilation rate, $E$ - transpiration rate, $W U E$ - water use efficiency, $P N U E$ - photosynthetic nitrogen use efficiency. $r$ - Pearson's coefficient of correlation, ${ }^{*} 0.01 \leq P<0.05$, ${ }^{* *} 0.001 \leq P<0.01,{ }^{* * *} P<0.001$, in bold $-r$ statistically significant $(N=17)$

Structural and physiological Pearson's coefficient of correlation parameters

\begin{tabular}{|c|c|c|c|}
\hline & LL & ML & $\mathrm{HL}$ \\
\hline $\mathrm{Chl}$ tot $\left(\mathrm{mg} \mathrm{m}^{-2}\right)$ & -0.389 & -0.253 & -0.429 \\
\hline $\mathrm{N}\left(\mathrm{mg} \mathrm{g}^{-1}\right)$ & 0.314 & 0.187 & 0.196 \\
\hline $\mathrm{N}\left(\mathrm{g} \mathrm{m}^{-2}\right)$ & $0.530^{*}$ & -0.229 & 0.215 \\
\hline $\mathrm{F}_{\mathrm{v}} / \mathrm{F}_{\mathrm{m}}$ & $-0.609^{*}$ & 0.170 & 0.355 \\
\hline $\mathrm{R}_{\mathrm{d}}\left(\mu \mathrm{mol} \mathrm{m} \mathrm{m}^{-2} \mathrm{~s}^{-1}\right)$ & -0.098 & -0.169 & -0.322 \\
\hline $\mathrm{R}_{\mathrm{d}}\left(\mathrm{nmol} \mathrm{g} \mathrm{g}^{-1} \mathrm{~s}^{-1}\right)$ & 0.131 & -0.426 & -0.370 \\
\hline$A_{\max }\left(\mu \mathrm{mol} \mathrm{m} \mathrm{m}^{-2} \mathrm{~s}^{-1}\right)$ & -0.416 & $0.706^{* *}$ & 0.338 \\
\hline $\mathrm{A}_{\max }\left(\mathrm{nmol} \mathrm{g} \mathrm{g}^{-1} \mathrm{~s}^{-1}\right)$ & -0.299 & $0.575^{*}$ & 0.104 \\
\hline $\mathrm{E}\left(\mathrm{mmol} \mathrm{m} \mathrm{m}^{-2} \mathrm{~s}^{-1}\right)$ & $-0.510^{*}$ & $0.541^{*}$ & 0.491 \\
\hline 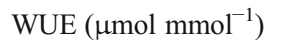 & $0.510^{*}$ & -0.241 & $-0.680^{* *}$ \\
\hline PNUE $\left(\mu \mathrm{mol} \mathrm{mmol}{ }^{-1}\right)$ & -0.378 & $0.591^{*}$ & 0.380 \\
\hline
\end{tabular}

Prunasin decreased with increasing $F_{v} / F_{m}$ in monoculture, but this trend was not significant in $\mathrm{Q}+\mathrm{P}+\mathrm{L}$ (Fig. 3a). The relationship between $A_{\max }$ expressed per unit leaf dry mass and prunasin concentration was positive in monoculture, but not significant in $\mathrm{Q}+\mathrm{P}+\mathrm{L}$ (Fig. 3b). Root prunasin decreased with declining $R_{\mathrm{d}}$ in monoculture and was nearly stable in $\mathrm{Q}+\mathrm{P}+\mathrm{L}$ (Fig. 3c).

Relationships between phosphorous, calcium, and root prunasin depended on the expression of their content per unit leaf dry mass or leaf area (Fig. 4a, b, c, d). Phosphorous content per DM increased linearly when expressed per unit leaf area in monoculture (Fig. 4b). In monoculture, leaf calcium content was positively related to root prunasin concentration, independently of being expressed per leaf DM or area, but not in $\mathrm{Q}+\mathrm{P}+\mathrm{L}$ (Fig. 4c, d).

\section{Discussion}

Seasonal Variation in Prunasin Concentration In roots of one-yr.-old $P$. serotina seedlings, prunasin varied during the vegetative season and was influenced by light conditions. In May, at the early stage of seedling development, concentration was lowest. It increased up to a maximum value in August, concurrent with air temperature and $P$. serotina growth rate. It 

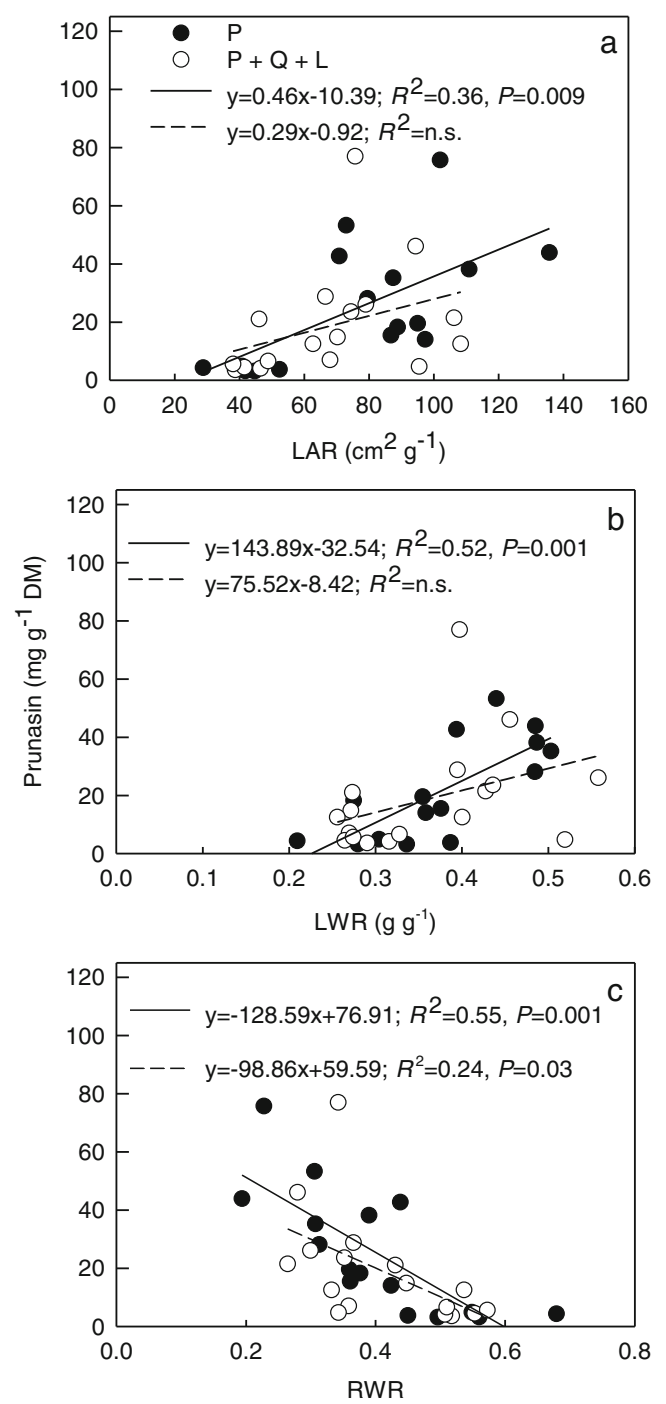

Fig. 2 The linear regression between the architectural parameters and prunasin concentration in roots of Prunus serotina seedlings growing in control (P - three Prunus seedlings) or in competition with mulching $(\mathrm{Q}+\mathrm{P}+\mathrm{L}$ - three Quercus petraea + six P. serotina + mulching with $P$. serotina leaves) under high light (HL): a Leaf area ratio $(L A R)$; b Leaf weight ratio $(L W R)$; c Root weight ratio $(R W R)$ vs. prunasin concentration in $P$. serotina roots. The equations of linear regression, coefficients of determination $\left(R^{2}\right)$ with probability $(P)$ obtained from the analysis of variance in regression are shown ( $N=16 ; N$ - number of seedlings)

declined in September, except for the seedlings growing in LL (Table 3). Results obtained in June in ML and HL and in September in ML were similar to those of Graham (2002), who reported prunasin concentrations of 12.8 to $14.5 \mathrm{mg} \mathrm{g}^{-1}$ $\mathrm{DM}$ in roots of Nemaguard peach seedlings grown in a greenhouse. In August, however, prunasin in roots was two to three times higher than in peaches. Around the same time, Miller et al. (2004) documented a mean prunasin concentration of $21.78 \mathrm{mg} \mathrm{g}^{-1} \mathrm{DM}$ in roots of Prunus turneriana (F.M.Bailey) Kalman, which is closely phylogenetically related to $P$. serotina.
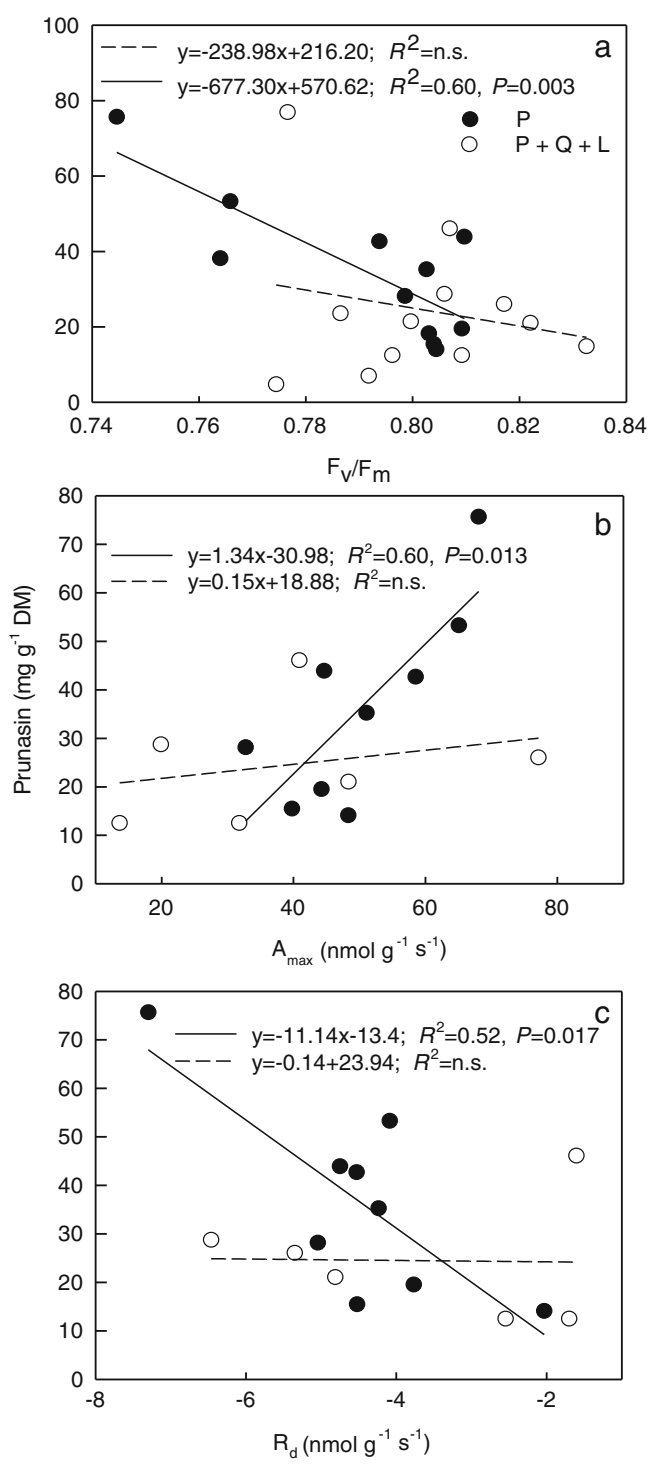

Fig. 3 The linear regression between the photosynthetic parameters and prunasin concentration in roots of Prunus serotina seedlings growing in control ( $\mathrm{P}$ - three Prunus seedlings) or in competition with mulching $(\mathrm{Q}+\mathrm{P}+\mathrm{L}-$ three Quercus petraea $+\operatorname{six}$ P. serotina + mulching with $P$. serotina leaves) under high light: a. Maximum quantum yield of PS II photochemistry $\left(F_{v} / F_{m}\right) ;$ b. Maximum net $\mathrm{CO}_{2}$ assimilation rate $\left(A_{\max }\right)$; c. Dark respiration $\left(R_{\mathrm{d}}\right)$ vs. prunasin concentration in Prunus serotina roots. The equations of linear regression, coefficients of determination $\left(R^{2}\right)$ with probability $(P)$ obtained from the analysis of variance in regression are shown $(N=9-11)$

In the present study, prunasin decreased exponentially with increasing water content in roots $\left(R^{2}=0.3, P<0.001\right)$ and was negatively correlated with photosynthetic water use efficiency in HL (Table 5). This is in agreement with earlier studies showing a decrease in root concentrations in Prunus dulcis Mill. and an increase in HCN release in lima bean grown under restricted water supply (Arzani et al. 2010; Ballhorn et al. 2011b).

Our study is the first to determine prunasin concentration in $P$. serotina roots on several occasions during the vegetative 
Fig. 4 The linear regression between phosphorous $(\mathrm{P})$ or calcium (Ca) content in leaves and prunasin concentration in roots of Prunus serotina seedlings growing in control $(\mathrm{P}$ - three Prunus seedlings) or in competition with mulching $(\mathrm{Q}+$ $\mathrm{P}+\mathrm{L}$ - three Quercus petraea + six $P$. serotina + mulching with $P$. leaves) under high light: a Phosphorous concentration in leaves expressed per leaf dry mass vs. prunasin concentration; b Phosphorous content per leaf area vs. prunasin concentration; c Calcium concentration per leaf dry mass vs. prunasin concentration; $\mathbf{d}$ Calcium content per leaf area vs. prunasin concentration in Prunus roots. The equations of linear regression, coefficients of determination $\left(R^{2}\right)$ with probability $(P)$ obtained from the analysis of variance in regression are shown $(N=8)$

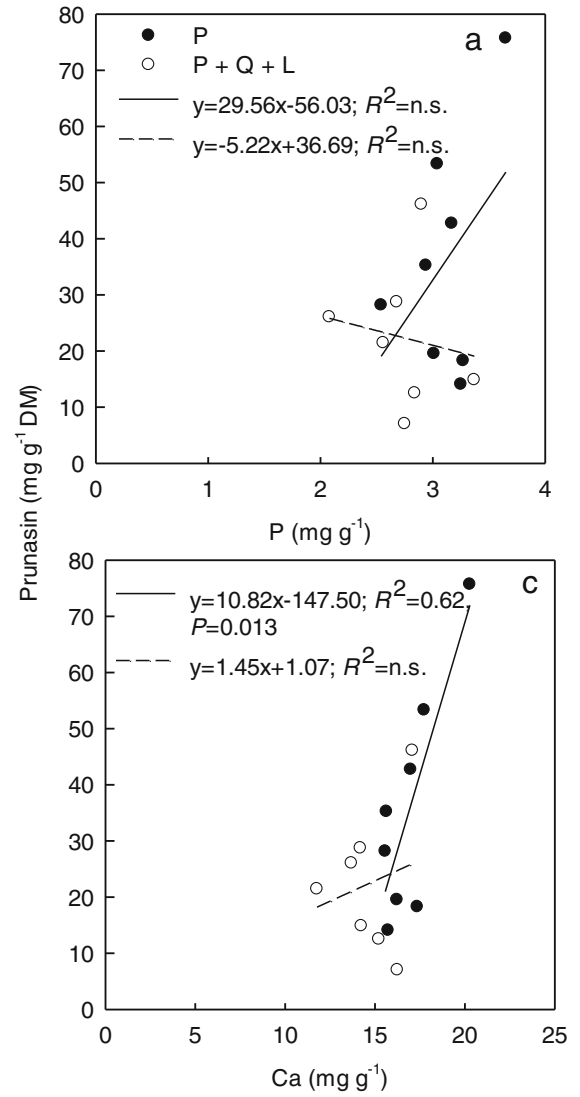

season. The course of changes was, to some extent, consistent with the results of earlier studies. This indicates that the amount of prunasin in leaves, twigs, and fruits depends on sampling time, plant developmental stage, and environmental conditions (Gleadow and Woodrow 2000; Neilson et al. 2013; Swain et al. 1992). Similar to our results, prunasin concentration in twigs and leaves of Amelanchier alnifolia (Nutt.) also varied seasonally (Majak et al. 1980). However, in A. alnifolia, prunasin decreased at the start of May and stabilized in July and August with diminishing intensity of photosynthesis.

Prunasin concentration also varied seasonally in young leaf tips of field-grown Eucalyptus cladocalyx (F. Muell.); seasonal variation was correlated with changes in leaf nitrogen content per unit leaf area (Gleadow and Woodrow 2000). In our study, prunasin root concentration was only weakly correlated with leaf nitrogen content expressed per unit leaf area in LL, where some trade-off was expected between investment of resources in defense against herbivores and light harvesting protein-pigment complexes (Neilson et al. 2013; Niinemets 1998). Root prunasin also has been positively correlated with leaf nitrogen in Prunus dulcis (Arzani et al. 2010).

In our study, prunasin concentration was linearly positively correlated with minimal monthly temperatures measured above the pots. Similarly, in Trifolium repens (L.), a positive correlation was found between total cyanogen content and mean air temperature for four days before sampling (Stochmal and Oleszek 1997). The results of Stochmal and Oleszek (1997) and our results suggest also that synthesis of cyanogenic glycosides increases in a warming climate. Thus, we hypothesize that these compounds, including prunasin, may not only play the role of an effective deterrent against insects or browsers when present in roots, twigs, and leaves (Ballhorn 2011; Patton et al. 1997), but also of a carbon store (Selmar et al. 1988). However, in leaves of cyanogenic Eucalyptus cladyocalyx, prunasin did not increase in elevated $\mathrm{CO}_{2}$ treatments (Gleadow et al. 1998).

In contrast, due to cyanogenesis, cyanogenic glycosides may become a source of carbon and nitrogen that can be reused in primary metabolism. In particular, such resources are translocated to photosynthetic processes and invested into photosynthetic structures contributing to an increase in $\mathrm{CO}_{2}$ uptake (Neilson et al. 2013). Cyanogenic glycosides synthesized in plant organs participate in carbon sequestration (Selmar et al. 1988). Plants may allocate a considerable amount of leaf nitrogen to prunasin - e.g., up to $20 \%$ in leaves of Eucalyptus cladocalyx (Gleadow and Woodrow 2000). Changes in concentrations of cyanogenic glycosides affect the balance of carbon and nitrogen in a plant, and may take part in carbon and nitrogen cycles as their sink or source. 
Light Effect on Prunasin Concentration When prunasin concentration in P. serotina roots was compared among experimental light environments, the highest values were found in LL, suggesting that it may protect roots of seedlings against insects and nematodes more effectively under shaded conditions. This result is consistent with the findings that shadeacclimated plants are more severely threatened by insects and might invest more resources into specialized metabolites with deterring properties, such as phenols and tannins (Karolewski et al. 2010, 2013). Here, however, the light effect was strongly influenced by sampling time (Table 2). This interaction was even more significant $(P=0.002)$ than the light effect itself $(P=0.045)$, indicating that when growth is inhibited in LL, prunasin synthesis is not reduced. Thus, higher prunasin concentrations in LL than in HL may be due to the fact that it is concentrated in a smaller root mass compared to HL. In our study, a shift in ontogenetic development affected, at least to some extent, the observed differences in root prunasin concentrations among light treatments.

Correlations between prunasin concentration in P. serotina roots and some morphological and architectural parameters depended on the light environment and were not observed in LL, when growth of seedlings was substantially inhibited (Table 4). For the most part, structural and physiological parameters correlated with prunasin concentration in $\mathrm{LL}$ and $\mathrm{ML}$ (Table 5). According to resource allocation theory, when shading inhibits growth more than it decreases photosynthesis, $P$. serotina seedlings should invest more resources into prunasin and structural and physiological processes (Table 5) (Matyssek et al. 2005). In contrast, however, Burns et al. (2002) showed that in LL, prunasin concentration in Eucalyptus cladocalyx leaf was lower than in HL. Additionally, those authors concluded that the slope of linear regression between total leaf nitrogen concentration and leaf cyanide concentration depends on light conditions, suggesting that differences in prunasin concentration can be explained by the optimal resources allocation hypothesis.

In our study, the lower prunasin concentration in P. serotina roots in HL likely results from the allocation of resources to photosynthetic processes and growth. Additionally, in HL, nitrogen and carbon may be translocated into the xanthophyll cycle or other mechanisms that protect against photoinhibition. These observations are supported to some extent by Jørgensen et al. (2005), who demonstrated that in cassava, cyanogenic glucosides are transported from the shoots to the roots. Additionally, Gleadow and Woodrow (2000) have shown a significant decrease in the proportion of nitrogen allocated to cyanogenic glucosides in young Eucalyptus cladocalyx leaves, coinciding with the peak flowering period. This implies that nitrogen from cyanogenic glycosides is transferred from young leaves to reproductive organs.
According to the optimal resources allocation hypothesis (McKey 1974), high prunasin concentration in P. serotina roots in LL is determined by two factors: (1) the cost for P. serotina seedlings of herbivore-inflicting damage or root loss, and (2) the probability that the roots would be successfully attacked in the absence or low concentration of prunasin. Our results suggest that under LL, photosynthetic gain can be maximized by the reallocation of nitrogen from root defense to the photosynthetic system. However, in LL, an increase in root prunasin occurred at the cost of maximal quantum yield of PSII photochemistry. In contrast to our study, Miller et al. (2004) found no difference in cyanogenic glycoside concentration nor the proportion of nitrogen allocated to cyanogenic glycoside in foliage, stems, or roots of Prunus turneriana (F.M.Bailey) Kalkman when comparing plants grown in one of three light treatments.

\section{Effects of Interspecific Competition on Prunasin} Concentration According to some studies, plants rich in prunasin are more competitive than others species (Badri and Vivanco 2009; Bais et al. 2004, 2006). Hypothetically, in the presence of a competitive species, $Q$. petraea, prunasin in roots of invasive P. serotina acts as a "novel weapon" (Kim and Lee 2010). Here, prunasin levels were similar in the monoculture and competition treatments (Table 2). This result indicates that synthesis of prunasin in P. serotina roots was not stimulated by interspecific competition. Nevertheless, in Prunus monocultures growing in HL, prunasin concentrations were linearly correlated with growth, biomass allocation, and some physiological parameters of $P$. serotina seedlings. However, such relationships were not found in Prunus seedlings growing in Q + $\mathrm{P}+\mathrm{L}$ (Figs. 2 and 3). In the HL treatment only, the presence of Q. petraea influenced the relationships between the measured features and prunasin concentration when compared with $P$. serotina seedlings grown in monoculture. In other words, competition with $Q$. petraea did not directly affect the quantity of prunasin in roots of $P$. serotina seedlings, but influenced the relationships between prunasin concentration and morphological and physiological features modulated by light conditions. This suggests that $P$. serotina growing in interspecific competition utilize a different strategy for prunasin use compared to $P$. serotina growing in monocultures. This difference can be explained by the hypothesis that the costs of reallocating prunasin from roots to leaves, structural traits, and photosynthetic capacity are probably different in P. serotina growing in monocultures than seedlings growing in the interspecific competition treatment where prunasin concentration was not correlated with these parameters, thus suggesting that an investment of resources into competition with $Q$. petraea occurred at the expense of reallocating nitrogen from prunasin to growth and photosynthesis. Still, there is a need to re-evaluate resource allocation-based hypotheses regarding prunasin costs and to consider how multifunctional attributes of prunasin may lower the cost of interspecific competition (Neilson et al. 2013). 
Our study emphasizes that variation in prunasin concentration is the result of species-specific adaptation, microclimatic conditions, a shift in ontogenetic development, and, to a lesser extent, interspecific plant-plant interactions. The effect of sampling time, which integrated the effects of changing microclimatic conditions and ontogenetically determined growth dynamics of $P$. serotina seedlings, seemed to be the most pronounced one.

Under LL, nitrogen in excess of growth and photosynthetic requirements seems to be allocated to prunasin in $P$. serotina roots, and this increase in prunasin would in turn lead to a decrease in $F_{v} / F_{m}$ (Table 5). Inversely, under ML and HL, relatively more nitrogen was invested in biomass production, photosynthesis, and photoprotection (in HL) at the expense of prunasin synthesis. Interestingly, in ML, an increase in prunasin concentration was associated with higher net $\mathrm{CO}_{2}$ assimilation rates and $P N U E$, which suggests a trade-off between increasing $A_{\max }$ due to higher $P N U E$ and greater prunasin concentration (Table 4). In Eucalytptus cladocalyx, there was an approximately proportional increase in cyanogenic glycoside concentration with leaf nitrogen concentration (Gleadow et al. 1998). However, Goodger et al. (2004) did not find a significant increase in prunasin when $E$. polyanthemos seedlings were grown at high soil nitrogen availability. In our study, where the seedlings were fertilized, relations between prunasin concentration, phosphorous, and calcium were driven by light regimes and, to a lesser extent, by competitive interactions (Fig. 4).

Selmar et al. (1988) demonstrated that linamarin, and possibly other cyanogenic glycosides, serve in the metabolism of developing plants as N-storage compounds. The behavior of $P$. serotina in LL indicates that it is an opportunistic species that can store nitrogen in the form of prunasin even in deep shade where its growth is limited. Under more favorable light conditions, the resources stored in root prunasin might be transformed and transported to leaves and reused for photosynthesis and biomass production. This is in agreement with similar studies showing that $P$. serotina seedlings initially grow slowly under a dense canopy of young Scots pine forest, while their growth is seven times faster under a more open canopy (Robakowski and Bielinis 2012). In P. serotina, prunasin may effect ecological plasticity and invasiveness in response to climate change and competition. Unraveling the coexisting physiological, genetic, and ecological mechanisms influencing prunasin concentration in $P$. serotina roots remains a significant future challenge.

Acknowledgments We thank Monika Robakowska for language revision and Dr. Kerrie Sendall for language revision and valuable comments. We also thank the anonymous reviewers for comments that substantially improved our manuscript. We thank all undergraduate students for their participation in growth measurements. This study was supported by Ministry of Science and Higher Education Research Grant N N309 02639 .
Open Access This article is distributed under the terms of the Creative Commons Attribution 4.0 International License (http:// creativecommons.org/licenses/by/4.0/), which permits unrestricted use, distribution, and reproduction in any medium, provided you give appropriate credit to the original author(s) and the source, provide a link to the Creative Commons license, and indicate if changes were made.

\section{References}

Agrawal AA, Hastings AP, Johnson MTJ, Maron JL, Salminen J (2012) Insect Herbivores Drive real-time ecological and evolutionary change In Plant populations. Science 338:113-116

Arzani K, Yadollahi A, Ebadi A, Wirthensohn M (2010) The relationship between bitterness and drought resistance of almond (Prunus dulcis Mill.). Afric J Agric Res 5:861-866

Badri DV, Vivanco JM (2009) Regulation and function of root exudates. Plant Cell Environ 32:666-681

Bais HP, Fall R, Vivanco JM (2004) Biocontrol of Bacillus subtilis against infection of Arabidopsis roots By Pseudomonas syringae is facilitated by biofilm formation and surfactin production. Plant Physiol 134:307-319

Bais HP, Weir TL, Perry LG, Gilroy S, Vivanco JM (2006) The role Of root exudates In rhizosphere interactions with plants and other organisms. Annu Rev Plant Biol 57:233-266

Ballhorn DJ (2011) Constraints of simultaneous resistance to a fungal pathogen and an Insect herbivore in Lima Bean (Phaseolus lunatus L.). J Chem Ecol 37:141-144

Ballhorn DJ, Kautz S, Jensen M, Schmitt I, Heil M, Hegeman AD (2011a) Genetic and environmental interactions determine plant defences against herbivores. J Ecol 99:313-326

Ballhorn DJ, Schmitt I, Fankhauser JD, Katagiri F, Pfanz H (2011b) $\mathrm{Co}_{2}-$ mediated changes of plant traits and their effects on herbivores are determined by leaf age. Ecol Entomol 36:1-13

Berenguer-Navarro V, Ginger-Galvan RM, Grane-Teruel N (2002) Chromatographic determination of cyanoglycosides prunasin and amygdalin in plant extracts using a porous graphitic carbon column. J Agric Food Chem 50:6960-6963

Brooke BM, Mcdiarmid RE, Majak W (1984) The cyanide potential in two varieties of Amelanchier alnifolia. Can J Plant Sci 543:543-547

Burns AE, Gleadow RM, Woodrow I (2002) Light alters the allocation of nitrogen to cyanogenic glycosides in Eucalyptus cladocalyx. Oecologia 133:288-294

Burns AE, Gleadow RM, Zacarias M, Miller RE, Cavagnaro TR (2012) Variations in the chemical composition of cassava (Manihot esculenta Crantz) leaves and roots As affected by genotypic and environmental variation. J Agric Food Chem 60:4946-4956

Cooper-Driver G, Finch S, Swain T, Bernays E (1977) Seasonal variation in secondary plant compounds in relation to the palatability of Pteridium aquilinum. Biochem Syst Ecol 5:177-183

Csiszár Á, Korda M, Schmidt D, Šporčić D, Süle P, Teleki B, Tiborcz V, Zagyavai G, Bartha D (2013) allelopathic potential of some invasive plant species occurring in Hungary. Allelopath $\mathrm{J}$ 31:309-318

De Nicola GR, Leoni O, Malaguti L, Bernardi R, Lazzeri L (2011) A simple analytical method for dhurrin content evaluation in cyanogenic plants for their utilization in fodder and biofumigation. J Agric Food Chem 59:8065-8069

Del-Val EK, Crawley MJ (2005) What limits herb biomass in grasslands: competition or herbivory? Oecologia 142:202-211

Dicenta F, Martinez-Gomez P, Grane N, Martin ML, Leon A, Canovas JA, Berenguer V (2002) Relationship between cyanogenic compounds in kernels, leaves, and roots of sweet and bitter kernelled almonds. J Agric Food Chem 50:2149-2152 
Du L, Bokanga M, Møller BL, Halkier BA (1995) The biosynthesis of cyanogenic glucosides in roots of cassava. Phytochemistry 39:323-326

Forestry Compendium (2005) Quercus petraea. In: Forestry Compendium, Global edition. Wallingford: Cab International

Giertych MJ, Suszka J (2011) Consequences of cutting off distal ends of cotyledons of Quercus robur acorns before sowing. Ann For Sci 68: 433-442

Gleadow RM, Møller BL (2014) Cyanogenic glycosides: synthesis, physiology, and phenotypic plasticity. Annu Rev Plant Biol 65:155-185

Gleadow RM, Woodrow IE (2000) Temporal and spatial variation in cyanogenic glycosides in Eucalyptus cladocalyx. Tree Physiol 20: $591-598$

Gleadow RM, Foley WJ, Woodrow IE (1998) Enhanced $\mathrm{Co}_{2}$ alters the relationship between photosynthesis and defence In Cyanogenic Eucalyptus cladocalyx F. Muell. Plant Cell Environ. 21:12-22

Goodger JQD, Ades PK, Woodrow IE (2004) Cyanogenesis in Eucalyptus polyanthemos seedlings: heritability, ontogeny and effect of soil nitrogen. Tree Physiol 24:681-688

Graham CJ (2002) Nonstructural carbohydrate and prunasin composition of peach seedlings fertilized with different nitrogen sources and aluminium. Sci Hortic-Amsterdam 94:21-32

Halarewicz A (2011) The reasons underlying the invasion of forest communities by P. serotina, Prunus serotina and its subsequent consequences. For Res Pap 72:267-272

Hernández T, Lundquist P, Oliveira L, Cristià RP, Rodriguez E, Rosling H (1995) Fate in humans of dietary intake of cyanogenic glycosides from roots of sweet cassava consumed in Cuba. Nat Toxins 3:114-117

Hunt R, Causton DR, Shipley B, Askew AP (2002) A modern tool for classical plant growth analysis. Ann Bot 90:485-488

Jørgensen K, Bak S, Busk PK, Sørensen C, Olsen CE, Puonti-Kaerlas J, Møller BL (2005) Cassava plants with a depleted cyanogenic glucoside content in leaves and tubers. Plant Physiol 139:363-374

Karolewski P, Zadworny M, Mucha J, Napierała-Filipiak A, Oleksyn J (2010) Link between defoliation and light treatments on root vitality of five understory shrubs with different resistance to insect herbivory. Tree Physiol 30:969-978

Karolewski P, Giertych MJ, Żmuda M, Jagodziński AM, Oleksyn J (2013) Season and light affect constitutive defences of understory shrub species against folivorous insects. Acta Oecol 53:19-32

Kenk KG (1993) New perspectives in german oak silviculture. Ann Sci For 50:563-570

Kim YO, Lee EJ (2010) Comparison of phenolic compounds and the effects of invasive and native species in East Asia: support for the novel weapons hypothesis. Ecol Res 26:87-94

Leavesley HB, Li L, Prabhakaran K, Borowitz JL, Isom GE (2008) interaction of cyanide and nitric oxide with cytochrome $\mathrm{c}$ oxidase: implications for acute cyanide toxicity. Toxicol Sci 101:101-111

Lieberei R (2006) Physiological characteristics of Microcylus ulei (P. Henn.) V.Arx. - A fungal pathogen of the cyanogenic host Hevea brasilensis. J Appl Bot Food Qual 80:63-68

Majak W, Quinton DA, Broersma K (1980) Cyanogenic glycoside levels in saskatoon serviceberry. J Range Manag 33:197-199

Marquis, D. A. 1990 Prunus serotina Ehrh. P. Serotina. Silvics of North America 2:594-604

Matyssek R, Agerer R, Ernst D, Munch J-C, Oßwald W, Pretzsch H, Priesack E, Schnyder H, Treutter D (2005) The plant's capacity in regulating resource demand. Plant Biol 7:560-580

Mchugh TA, Gehring CA (2006) Below-ground interactions with arbuscular mycorrhizal shrubs decrease the performance of pinyon pine and the abundance of its ectomycorrhizas. New Phytol 171:171-178

Mckey D (1974) Adaptive patterns in alkaloid physiology. Am Nat 108: 305-320
Miller RE, Gleadow RM, Woodrow IE (2004) Cyanogenesis in tropical Prunus turneriana: characterisation, variation and response to low light. Funct Plant Biol 31:491-503

Möllerová J (2005) Notes on invasive and expansive trees and shrubs. J For Sci 2005:19-23

Mulas M (1994) Almond genetic resources and resistance to Capnodis tenebrionis. Acta Horticult 373:41-48

Neilson EH, Goodger JQD, Woodrow IE, Møller BL (2013) Plant chemical defence: at what cost? Trends Plant Sci 18:250-258

Niinemets U (1998) Are compound-leaved woody species inherently shade-intolerant? An analysis of species ecological requirements and foliar support costs. Plant Ecol 134:1-11

Okafor PN (2005) Determination of the hydrolytic activity of Achatina achatina $\beta$-glucosidease toward some cyanogenic glycosides of some tropical plants. Process Biochem 40:1579-1582

Patton CA, Ranney TG, Burton JD, Walgenbach JF (1997) Natural pest resistance of Prunus taxa to feeding by adult japanese beetles: role of endogenous allelochemicals in host plant resistance. J Am Soc Hortic Sci 122(5):668-672

Poorter H, Niklas KJ, Reich PB, Oleksyn J, Poot P, Mommer L (2012) Biomass allocation to leaves, stems and roots: meta-analyses of interspecific variation and environmental control. New Phytol. 193:30-50

Portsmuth A, Niinemets Ü (2007) Structural and physiological plasticity in response to light and nutrients in five temperate deciduous woody species of contrasting shade tolerance. Funct Ecol 21:61-77

Qiunn GP, Keough MJ (2002) Experimental design and data analysis for biologists. Cambridge University Press, New York, 557 pp

Reich PB, Tjoelker MG, Walters MB, Vanderklein DW, Buschena C (1998) Close association of RGR, leaf and root morphology, seed mass and shade tolerance in seedlings of nine boreal tree species grown in high and low light. Funct Ecol 12:327-338

Robakowski P, Bielinis E (2012) Competition between Q. petraea (Quercus petraea) and P. Serotina (Padus serotina): dynamics Of seedlings growth. Pol J Ecol 59:297-306

Sánchez-Pérez R, Belmonte FS, Borch J, Dicenta F, Møller BL, Jørgensen K (2012) Prunasin hydrolases during fruit development in sweet and bitter almonds. Plant Physiol 158:1916-1932

Selmar D, Lieberei R, Biehl B (1988) Mobilization and utilization of cyanogenic glycosides: the linustatin pathway. Plant Physiol 86: 711-716

Stochmal A, Oleszek W (1997) Changes of cyanogenic glucosides in white clover (Trifolium repens L.) during the growing season. J Agri Food Chem 45:4333-4336

Swain E, Poulton JE (1994a) Immunocytochemical localization of prunasin hydrolase and mandelonitrile lyase in stems and leaves of Prunus serotina. Plant Physiol 106:1285-1291

Swain E, Poulton JE (1994b) Utilization of amygdalin during seedling development of Prunus serotina. Plant Physiol 106:437-445

Swain E, Li CP, Poulton JE (1992) Development of the potential for cyanogenesis in maturing $P$. serotina (Prunus serotina Ehrh) fruits. Plant Physiol 98:1423-1428

Ubalua AO (2010) Cyanogenic glycosides and the fate of cyanide in soil. AJCS 4:223-237

Vetter J (2000) Plant Cyanogenic glycosides. Toxicon 38:11-36

Vickery PJ, Wheeler JL, Mulcahy C (1987) Factors affecting the hydrogen cyanide potential of white clover (Trifolium repens L.). Crop Pasture Sci 38:1053-1059

Wyka T, Robakowski P, Zytkowiak R (2007) Acclimation of leaves to contrasting irradiance in juvenile trees differing in shade tolerance. Tree Physiol 27:1293-1306

Zarzycki K, Trzcińska-Tacik H, Różański W, Szeląg Z, Wolek J, Korzeniak U (2002) Ecological indicator values of vascular plants of Poland. Szafer Institute of Botany, Pas, Kraków, 96 Pp 